\title{
Internalisasi Nilai-Nilai Multikultural Dalam Pengelolaan Pendidikan Di SMA Negeri I Randangan
}

\author{
Ketut Suardika, Siti Roskina Mas, Nina Lamatenggo \\ Program Studi Magister Administrasi Pendidikan \\ Universitas Negeri Gorontalo, 2019 \\ E-mail: suardikaketut@gemail.com
}

Received: 13 August 2021; Revised: 02 October 2021; Accepted: 21 December 2021

DOI: http://dx.doi.org/10.37905/aksara.8.1.257-268.2022

\begin{abstract}
Abstrak
Tujuan penelitian ini mendeskripsikan tentang: (1) nilai-nilai multikultural yang dikembangkan dalam kegiatan intrakurikuler dan ekstrakurikuler dan (2) metode internalisasi nilai-nilai multikultural di SMA Negeri I Randangan. Penelitian ini menggunakan pendekatan deskriptif kualitatif, dengan rancangan studi kasus. Informan dalam penelitian ini berjumlah 9 orang terdiri dari kepala sekolah, wakasek, guru, dan pegawai TU. Teknik pengumpulan data yang digunakan yakni wawancara mendalam, observasi berpartisipasi, dan studi dokumentasi. Teknik analisis data meliputi reduksi data, penyajian data, penarikan kesimpulan dan verifikasi. Hasil penelitian menunjukkan bahwa: (1) Nilai-nilai multikultur yang dikembangkan meliputi: (a) nilai saling menghargai, (b) nilai demokrasi, (c) nilai toleransi, (d) nilai keharmonisan dan (e) nilai keadilan dan kesetaraan. Pada pengelolaan pendidikan yang menginternalisasi nilia-nilai multikultur dilakukan dengan beberapa metode, yakni internalisasi melalui: (i) visi dan misi sekolah, (ii) mata pelajaran, (iii) kegiatan ekstrakurikuler, (iv) penataan lay out kelas dan pemberian tugas, dan (v) kegiatan perayaan hari besar keagamaan dan nasional.
\end{abstract}

KataKunci: Pengelolaan Pendidikan, Nilai Multikultural, Budaya Sekolah, Implikasi Nilai Multikultural

\section{PENDAHULUAN}

Pendidikan merupakan indikator penting yang menentukan kemajuan sebuah bangsa (Aziizu, 2015). Pendidikan berlangsung untuk mengembangkan potensi peserta didik menjadi lebih baik. Dalam pendidikan terdapat nilai-nilai yang perlu ditumbuhkan dalam jiwa peserta didik. Nilai pendidikan multikultural merupakan suatu standar perilaku yang diyakini dalam diri seseorang terkait keberagaman. Nilai pendidikan multikultural diantaranya yaitu keadilan, kemanusiaan, dan toleransi. Nilai keadilan merupakan sikap menempatkan sesuatu sesuai dengan yang kenyataannya. Nilai kemanusiaan merupakan sikap memelihara hubungan baik dengan sesamanya. Nilai toleransi merupakan sikap menghargai perbedaan yang ada dalam kehidupan masyarakat.

Pemicu konflik sering kali terjadi karena kurangnya pemahaman tentang nilainilai multikultural dikalangan peserta didik. Hal ini menjadi ancaman tersendiri yang mengakibatkan sikap tidak menghargai dan menghormati terhadap individu atau kelompok lainnya. Dampak buruk ialah munculnya konflik berkepanjangan yang mengakibatkan terjadinya tawuran antar pelajar, persekusi, sikap bullying, hal ini karena kurangnya sikap saling menghargai diantara para peserta didik. Untuk menghindari dampak negatif tersebut sangat perlu penanaman moral, etika, dan sikap tenggang rasa melalui pendidikan multikultural. Sebab, kodrat manusia diciptakan dengan beragam suku, agama, ras, yang secara sosio-budaya religius juga berbeda.

Pendidikan multikultural mengandung makna yang kompleks yakni pendidikan tentang keberagaman budaya, menghargai pluraritas dan heterogenitas karena 
perbedaan ras, etnik, kelas sosial dan kelompok budaya (Dawan, 2003; Sulalah, 2011; Gollnick dan Chinn, 2006; Mahfud, 2010; Abdullah, 2005). Multikultural lahir dari refleksi terhadap suatu kelompok (Mashuri, 2016), yang mengeksplorasi perbedaan sebagai anugerah dari Tuhan (Mahfud, 2014), dengan menanamkan sikap persamaan, saling menghormati (pluralitas dan heterogenitas), tulus, serta toleran terhadap keberagaman (Naim dan Sauqi, 2010; Kasinyo, 2012; Furkan 2012). Lebih dari itu peserta didik diajari untuk memahami mengakui dan menghormati bahwa tiap golongan memiliki hak untuk menyatakan diri menurut caranya masing-masing. Pada pengajaran pendidikan multikultural, para peserta didik sedini mungkin dibimbing untuk memahami makna bineka tunggal ika dan mengimplementasikan kehidupan sehari-hari.

Aspek yang menjadi kunci dalam melaksanakan pendidikan multikultural di sekolah ialah: (1) tidak adanya kebijakan yang menghambat toleransi, termasuk tidak adanya penghinaan terhadap ras, etnis dan jenis kelamin; (2) menumbuhkan kepekaan terhadap perbedaan budaya, di antaranya mencakup pakaian, music, dan makanan kesukaan; dan (3) memberikan kebebasan kepada siswa dalam merayakan hari besar umat beragama serta memperkuat sikap siswa agar merasa perlu terlibat dalam pengambilan keputusan secara demokratis

Sebagai lembaga sekolah favorit dan juga di bawah naungan pemerintah dan dinas pendidikan, didalamnya terdapat keberagaman dan sangat heterogen. Data keberagaman etnis/suku di SMA Negeri I Randangan, dari 390 Siswa terdapat Suku Gorontalo sebanyak 271 orang $(69,5 \%)$, Jawa 49 orang (12,6\%), Bugis 32 orang $(8,2 \%)$, Bali 30 orang $(7,7 \%)$, Toraja 2 orang $(0,5 \%)$, Minahasa 2 orang $(0,5 \%)$, Kaili 1 orang $(0,3 \%)$, Sangir 2 orang $(0,5 \%)$, dan Suku Lombok 1 orang $(0,3 \%)$. Adanya keberagaman dan perbedaan kultur tersebut akan rentan terjadinya perselisihan dan konflik dalam interaksi siswa di lingkungan sekolah.

Internaisasi dapat diakatakan sebagai proses penanaman konsep, ide, gagasan sekaligus belajar terhadap nilai-nilai dan norma sosial masyarakat (Arofah, 2014; Kalidjernih, 2010; Scott, 2007), yang memiliki tujuan secara normatif, fungsional dan operasional (Mujib dan Mudzakkir, 2006). Penanaman nilai-nilai multikultural menjadi satu alternatif melalui penerapan strategi dan konsep pendidikan yang berbasis pada pemanfaatan keragaman yang ada di masyarakat, khususnya yang ada pada siswa seperti pada keragaman etnis, budaya, bahasa, agama dan ras.

\section{METODE PENELITIAN}

Penelitian ini dilaksanakan di SMA Negeri I Randangan Desa Motolohu Kecamatan Randangan Kabupaten Pohuwato Provinsi Gorontalo, waktu penelitian dilaksanakan dari Bulan Mei sampai dengan Juli 2019.

Pendekatan yang digunakan dalam penelitian ini adalah pendekatan deskriftif kualitatif. Digunakan pendekatan kualitatif karena adanya kesesuaian antara karakteristik dan ciri-ciri yang cocok, diantaranya : (1) instrumen utamanya adalah manusia/ Peneliti, (2) bersifat deskriftif, (3) kerja lapangan, dan (4) holistik (Moleong, 2006).

Jenis penelitian ini adalah studi kasus. Penelitian studi kasus ini diarahkan untuk mengungkapkan suatu pristiwa atau kejadian tentang internalisasi nilai-nilai multikultur dalam pengelolaan pendidikan yang meliputi kesiswaan ketenagaan terutama guru dan tenaga kependidikan. 
Kehadiran peneliti di lapangan sebagai instrumen kunci dalam penelitian kualitatif dimaksudkan untuk mengobservasi secara langsung fenomena yang berhubungan dengan internalisasi nilai-nilai multikultur dalam pengelolaan pendidikan. Untuk memperoleh data yang diinginkan dengan mudah dan lengkap, peneliti harus membangun kepercayaan yang tinggi dan menghindarkan kesan-kesan yang merugikan informan. Kehadiran dan keterlibatan peneliti di lapangan harus diketahui secara terbuka oleh subyek penelitian. Sehubungan dengan itu peneliti mengambil langkahlangkah sebagai berikut: (1) peneliti bertemu dengan kepala sekolah untuk memohon izin melaksanakan penelitian, (2) mengadakan survei di lapangan untuk memahami latar penelitian yang sebenarnya (3) melaksanakan kunjungan untuk mendapatkan informasi awal penelitian.

Penentuan sumber-sumber data pada penelitian ini dilakukan secara purposive sampling karena sampling didasarkan pada tujuan (relevansi) dan kedalaman informasi yang akan dijaring. Sumber data dimaksud digambarkan pada Tabel 1.

Tabel 1. Data Informan Penelitian di SMA Negeri I Randangan

\begin{tabular}{|c|c|c|c|c|}
\hline informan & Nama & Kode & Volume & Keterangan \\
\hline Kepala Sekolah & $\begin{array}{l}\text { Rahim } \\
\text { Nusi,SPd }\end{array}$ & $\mathrm{RN}$ & $3 X$ & $\begin{array}{l}\text { Memahami persis } \\
\text { tentang permasalahan } \\
\text { yang hendak diteliti }\end{array}$ \\
\hline $\begin{array}{l}\text { Wakil Kepala } \\
\text { Sekolah }\end{array}$ & La Samula,SPd & LS & $4 X$ & $\begin{array}{ll}\text { Banyak } & \text { memahami } \\
\text { tentang } & \text { permasalah } \\
\text { siswa } & \end{array}$ \\
\hline $\begin{array}{l}\text { Guru } \\
\text { Suku Gorontalo }\end{array}$ & $\begin{array}{l}\text { Abdul Halim } \\
\text { Adam,SPd }\end{array}$ & AHA & $3 X$ & $\begin{array}{lr}\text { Memahami } & \text { betul } \\
\text { tentang } & \text { perbedaan } \\
\text { cultural suku gorontalo }\end{array}$ \\
\hline Guru Suku Bali & $\begin{array}{l}\text { I Nengah } \\
\text { Budorasa,SPd }\end{array}$ & NB & $3 X$ & $\begin{array}{l}\text { Memahami betul } \\
\text { tentang perbedaan } \\
\text { cultural suku Bali }\end{array}$ \\
\hline Guru Suku Jawa & $\begin{array}{l}\text { Dedi Artanto } \\
\text {,SPd }\end{array}$ & DA & $3 X$ & $\begin{array}{l}\text { Memahami } \text { betul } \\
\text { tentang perbedaan } \\
\text { cultural suku Jawa }\end{array}$ \\
\hline Guru Suku Buton & Sarsina,SPd & $\mathrm{S}$ & $3 X$ & $\begin{array}{l}\text { Memahami } \quad \text { betul } \\
\text { tentang perbedaan } \\
\text { cultural suku Buton }\end{array}$ \\
\hline $\begin{array}{l}\text { Guru } \\
\text { Suku minahasa }\end{array}$ & $\begin{array}{l}\text { Meylin M.J } \\
\text { Hutajuhu,S,Te } \\
\text { ol }\end{array}$ & MMJH & $3 X$ & $\begin{array}{l}\text { Memahami betul } \\
\text { tentang perbedaan } \\
\text { cultural suku Minahasa }\end{array}$ \\
\hline Pegawai & $\begin{array}{l}\text { Suryanti } \\
\text { Sunge,S.Ap }\end{array}$ & SRS & $2 X$ & $\begin{array}{l}\text { Memahami tentang data } \\
\text { siswa yang berbeda } \\
\text { kulturnya }\end{array}$ \\
\hline Pegawai & Mutna Mohi & $\mathrm{MM}$ & $2 X$ & $\begin{array}{l}\text { Memahami tentang data } \\
\text { siswa yang berbeda } \\
\text { kulturnya }\end{array}$ \\
\hline
\end{tabular}


Untuk memperoleh data secara holistis dan integrafis di lapangan serta memperhatikan relevansi data, fokus, dan tujuan dalam pengumpulan data digunakan tiga tehnik, yaitu: (1) wawancara mendalam (in deft interview), (2) observasi partisipasi, dan (3) studi dokumentasi. Ketiga tehnik tersebut merupakan tehnik dasar dalam penelitian kualitatif (Bogdan dan Biklen, 1982).

Proses analisis data yang dilakukan dalam penelitian ini mengacu kepada proses analisis data yang disampaikan oleh Hadi (2004) dan Sugiyono (2013) yaitu: setelah data dibaca, dipelajari, dan ditelaah, maka selanjutnya data direduksi, disajikan, dan ditarik kesimpulan serta verifikasinya. Komponen-komponen analisis data kualitatif adalah sebagai berikut:

\begin{tabular}{|c|c|c|c|}
\hline \multirow[b]{2}{*}{ Antisipasi } & \multicolumn{3}{|c|}{$\begin{array}{l}\text { Masa Pengumpulan Data } \\
\text { REDUKSI DATA }\end{array}$} \\
\hline & Selama & Pasca & \\
\hline \multirow{2}{*}{\multicolumn{3}{|c|}{ PENYAJIAN DATA }} & \\
\hline & & & \\
\hline & \multicolumn{3}{|c|}{ PENARIKAN KESIMPULAN/VERIFIKASI } \\
\hline & Selama & Pasca & \\
\hline
\end{tabular}

Gambar 1. Komponen dan Proses Analisis Data

Sumber Diadaptasi dari Miles dan Huberman (1984) berikut:

Penjelasan dari masing-masing tahapan analisis tersebut dijabarkan sebagai

1. Redukasi data. Dalam mereduksi data peneliti melakukan beberapa langkah yakni: Pertama, melakukan pengkodean data terlebih dahulu dari hasil wawancara, catatan lapangan dan observasi yang peneliti lakukan. Kedua, peneliti melakukan penyortiran data, dari hasil kode yang telah dibuat pada langkah pertama kemudian disortir, dibaca kembali dari setiap jawaban informan dan catatan lapangan yang telah tertera koding tadi. Ketiga, selanjutnya peneliti melakukan analisis komparatif dengan melakukan crosschek dengan sumber data lainnya.

2. Penyajian data. Dalam penelitian ini maksud penyajian data dilakukan dalam bentuk uraian singkat hasil wawancara, catatan lapangan dan observasi yang telah dilakukan, dibuat dalam bentuk diagram konteks, dan disajikan pada tabel hasil penelitian.

3. Dalam penelitian ini kesimpulan awal yang dikemukakan masih bersifat sementara dan akan berubah bila peneliti menemukan kembali data-data yang lebih kuat pendukung penelitian. Oleh karenanya peneliti melakukan simpulan dan verifikasi selama dan pasca penelitian berlangsung. 


\section{HASIL DAN PEMBAHASAN}

\section{Nilai-Nilai Multikultur yang Dikembangkan}

Nilai-nilai multikultural tersebut terdiri dari: (1) nilai saling menghargai, (2) nilai demokrasi, (3) nilai toleransi, (4) nilai keharmonisan, dan (5) nilai keadilan dan kesetaraan (senasib sepenanggungan). Secara lebih rinci hasil penelitian terhadap nilainilai multikultur yang diterapkan sebagai berikut:

Nilai saling menghargai yaitu treatment yang dilakukan dalam rangka membelajarkan kepada siswa untuk saling menghargai dilakukan pada beberapa aspek hubungan, yakni: (1) saling menghargai antar sesama siswa yang berbeda agama, agama dan etnis, (2) saling menghargai antara siswa dan guru, (3) saling menghargai antara siswa dengan pegawai sekolah, dan (4) saling menghargai antara siswa dengan masyarakat. Dalam penanaman nilai saling menghargai, perilaku diterapkan melalui kegiatan keagamaan yang dilaksanakan pada masing-masing agama. Seperti contoh pemeluk agama Hindu dan Kristen menghargai rekan-rekan yang beragama Islam pada setiap melaksanakan ibadah sholat, demikian juga sebaliknya. Nilai demokrasi yaitu upaya memberikan ruang gerak dan kebebasan kepada siswa maka nilai demokrasi sangat dipertimbangkan untuk diinternalisasi dalam kegiatan pembelajaran di sekolah. Dari sudut organisasi sekolah, bahwa nilai demokrasi dapat dimaknai memberikan ruang yang sama kepada siswa untuk dapat berkiprah dalam organisasi sekolah seperti Osis, ataupun dalam setiap pemilihan delegasi kegiatan. Nilai toleransi yaitu mengarahkan siswa untuk menghindarkan perbuatan-perbuatan yang memojokkan, mencela, persekusi, dan menganggap kelompok satu lebih kuat dari kelompok lain. Nilai keharmonisan (senyum, salam, sapa) mengindikasikan adanya interaksi yang baik yang berlangsung di sekolah. Kondisi yang harmonis memiliki sifat keutuhan interaksi sosial dan selalu menjunjung asas kepatuhan dalam lingkungan sekolah. Nilai keadilan dan kesejahteraan disini adalah adil yang bersifat sosial, pengambilan keputusan dan adil secara material.

\section{Metode internalisasi nilai-nilai multikultural}

Pengembangan nilai-nilai multikultur dilakukan melalui beberapa metode/langkah yakni: (a) diinternalisasikan pada visi dan misi, (b) internalisasi dalam mata pelajaran, (c) internalisasi dalam kegiatan ekstrakurikuler, (d) penataan pada lay out kelas dan tugas, dan (e) internalisasi pada kegiatan hari besar keagamaan dan nasional. Masing-masing metode tersebut dijelaskan secara rinci sebagai berikut:

1) Internalisasi Nilai Multikultur Dalam Visi dan Misi Sekolah

Dalam mencapai keberhasilan di dunia pendidikan tentunya sekolah akan menetapkan apa yang disebut dengan visi dan misi. Hal ini akan menjadi patokan dalam penentuan arah atau tujuan utama dari sekolah tersebut. Dalam kaitannya dengan penelitian terhadap pengelolaan pendidikan yang menginternalisasi nilai-nilai multicultural.

2) Internalisasi Nilai Multikultur Dalam Mata Pelajaran

Metode internalisasi yang kedua adalah mengintegrasikan ke dalam mata pelajaran di sekolah. Internalisasi dalam mata pelajaran ini tidak pernah membedabedakan dari mana siswa itu bersal, agamanya apa, sukunya apa, kaya atau tidak, anaknya siapa. Seperti halnya disampaikan oleh guru mata pelajaran, yakni proses pembelajaran yang dilaksanakan selalu berusaha tidak mengedepankan salah satu 
budaya atau suku, melainkan selalu berorientasi terhadap keragaman yang ada pada kelas tersebut.

3) Internalisasi Nilai Multikultur Dalam Kegiatan Ekstrakurikuler

Selain diinternalisasikan pada pembelajaran di dalam kelas, nilai-nilai multikultur juga diintegrasikan pada kegiatan-kegiatan ekstrakurikuler. Hasil penelitian pada internalisasi nilai multikultur pada kegiatan ekstrakurikuler diungkapkan bahwa: Penerapan nilai-nilai multikultur diintegrasikan pada kegiatan: (1) upacara bendera dalam bahasa daerah, (2) pawai budaya, seperti dalam pelaksanaan pawai siswa ditugaskan untuk menampilkan pakaian adatnya masing-masing, (3) lomba tari daerah. Kegiatan-kegiatan ini dilakukan setiap tahunnya baik secara lokal, regional dan nasional. Disnilah siswa diikutsertakan untuk menampilkan keunikan-keunikan budaya masing-masing.

4) Internasisasi Nilai Multikultur Pada Lay Out Kelas dan Pemberian Tugas

Dalam upaya menginternalisasi nilai-nilai multikultur maka guru pada mata pelajaran seperti Pkn, Agama, Sejarah, Seni dan Budaya melakukan pengelolaan tata letak kelas (Lay out) dalam proses pembelajarannya. Tata letak itu seperti pengaturan kelas dilakukan silih berganti, misalkan dibuat berkelompok, lingkaran, saling berhadap-hadapan, bentuk "U", dan disesuaikan dengan kondisi ruang kelas. Ketika penugasan kelompok maka pengaturan kelas akan dibuat berkelompok, ketika diskusi dan ceramah maka pengaturan kelas dibuat seperti bentuk "U", hal ini untuk menjalin interaksi diantara siswa

5) Integrasi ke Dalam Kegiatan Perayaan Hari Besar Keagamaan dan Nasional

Meningkatkan rasa toleransi kepada siswa, maka pengelola sekolah juga membelajarkan siswa untuk saling berkunjung ke dalam perayaan hari besar keagamaan. Hal ini diungkapkan dalam hasil penelitian siswa turut berpartisipasi pada kegiatan keagamaan contoh penyemblihan hewan korban untuk agama Islam, dan perayaan hari natal bagi agam Kristen demikian juga dengan perayaan menjelang hari raya nyepi untuk agama Hindu. Disamping itu juga, siswa-siswa saling mengunjungi ketika datang hari besar masing-masing agama. Misalnya saat Idul Fitri, yang beragama Kristen dan Hindu datang berkunjung dan bersilaturahmi ke rumah siswa beragama Islam. 
Untuk memahami lebih jelas terhadap internalisasi nilai-nilai multikultur disajikan pada Gambar 2.

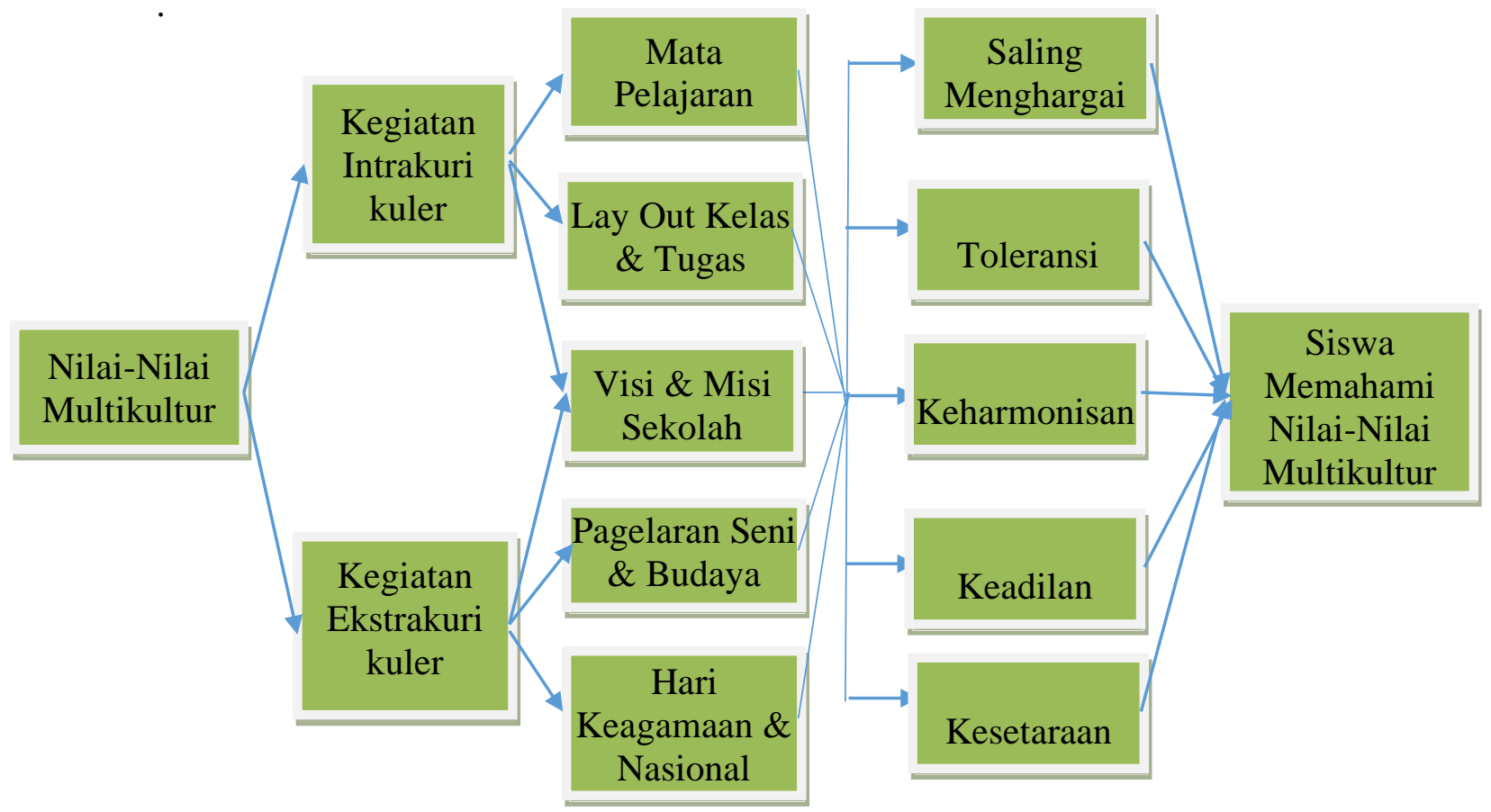

Gambar 2. Diagram Konteks Internalisasi Nilai-Nilai Multikultural di SMAN 1

\section{Pembahasan}

\section{Randangan}

\section{Nilai-Nilai Multikultur yang Dikembangkan}

Internalisasi nilai-nilai multikultural merupakan salah satu cara untuk mengenalkan keragaman kepada peserta didik tanpa mempermasalahakan perbedaan agama, gender, etnik, ras, suku, budaya, status sosial dan lain sebagainya (Satria, 2017).

Hasil penelitian menunjukkan bahwa nilai-nilai yang dikembangkan dalam kegiatan intrakurikuler dan ekstrakurikuler adalah: (a) nilai saling menghargai, (b) nilai demokrasi, (c) nilai toleransi, (d) nilai keharmonisan dan (e) nilai kesetaraan dan keadilan. Hasil ini diperkuat oleh Rufaida (2017), bahwa hasil kajian diperoleh nilainilai yang dikembangkan di sekolah yaitu nilai toleransi, saling menghargai dan menghormati. Usman dan Widyanto (2019), mengungkapkan bahwa nilai-nilai multikultur yang ditanamkan yakni: 1) Menghargai; 2) Bersaudara; 3) Kebebasan; 4) Kerjasama; 5) Tolong-menolong; 6) Tidak diskriminasi; dan 7) Berbagi. Demikian juga dilaporkan oleh Kamalia (2016), bahwa hasil dari internalisasi multicultural yakni memiliki nilai demokrasi, kesetaraan dan keadilan, berorientasi pada kemanusiaan, kebersamaan dan kedamaian, mengembangkan sikap mengakui, serta menerima dan menghargai keberagaman.

Keseluruhan hasil penelitian terhadap nilai-nilai multikultur yang dikembangkan dalam kegiatan intrakurikuler dan ekstrakurikuler tersebut dijelaskan sebagai berikut: 


\section{a. Saling Menghargai}

Orientasi penanaman nilai-nilai multikultural tidak lain berorientasi pada kemanusiaan. Hal ini dimaksud ialah adanya saling menghargai diantara manusia itu sendiri. Oleh karena itu sifat saling menghargai sangat dibutuhkan dalam rangka peningkatan martabat sebagai manusia. Dalam kasus ini, di lingkungan sekolah juga sangat dibutuhkan nilai saling mengahargai. Adanya pengembangan nilai saling menghargai di sekolah memberikan implikasi pada pengembangan potensi diri siswa untuk hidup bersama, bersatu, dan nyaman pergaulan di sekolah. Bisa dibayangkan jika nilai saling mengahrgai tidak diterapkan di sekolah, maka ketimpangan-ketimpangan sosial sudah tentu akan terjadi.

b. Nilai Demokrasi

Dalam hasil penelitian diperoleh bahwa arah dari internalisasi nilai demokrasi dalam pengelolaan pendidikan di sekolah arahnya ialah adanya kesetaraan, persamaan antara hak dan kewajiban. Lebih lanjut juga bahwa nilai demokrasi yang ditanamkan memberikan perlakuan yang sama di dalam proses kegiatan belajar dan mengajar yang dilakukan antara siswa dan pendidik, serta antara siswa dan tenaga kependidikan. Pada kegiatan di sekolah seluruh siswa diberikan kebebasan untuk berekpresi untuk mencapai prestasi yang optimal di sekolah. Karena sejatinya prinsip demokrasi di sekolah adalah dari siswa, oleh siswa dan untuk siswa, demi kemajuan lembaga pendidikan.

c. Nilai Toleransi

Nilai toleransi yang ditanamkan kepada siswa melingkupi berbagai aspek kehidupan di sekolah. Menurut penuturan informan bahwa pembianaan toleransi yang paling simpel adalah menerima dan memberikan kebebasan kepada agama lain untuk memeluk dan beribadah sesuai dengan kepercayaannya. Dari beranekaragam agama, dan tidak mono kepercayaan saja. Siswa diarahkan untuk dapat menerima, menghargai, memberikan pengakuan kepada kelompok-kelompok siswa lainnya baik dalam pemaknaan agama, suku, simbol-simbol keagamaan, pemaknaan hakikat peribadatan masing-masing agama. Pengakuan sekolah yang menerima seluruh elemen sistem yang bersifat pluralistik dan multikulturalistik. Mengapa penghargaan ini dilakukan tidak lain untuk mencapai kesempurnaan kondisi yang diidam-idamkan yakni kerukunan dan kedamaian.

\section{d. Nilai Keharmonisan}

Suasana yang ada begitu kondusif. Nilai harmonis dapat dilihat dari indikator tidak adanya percekcokan yang terjadi antara warga sekolah. Sikap harmonis disini yang tercermin ada tiga aspek yakni: (1) harmonis antar sesama warga sekolah. Hal ini ditandai dengan sikap pergaulan yang ditunjukkan sangat ramah dan baik. (2) harmonis kepada sang pencipta. Hal ini tercermin dari kegiatan-kegiatan keagamaan dan peribatan yang dilakukan, bahwa dari semua agama melakukan peribatannya masingmasing. Jika siswa muslim beribadah di masjid, non muslim beribadah di dalam kelas, karena fasilitas tempat ibadah yang terbatas. Namun tetap suasana terjaga dengan sangat harmonis. (3) harmonis dengan alam dan lingkungan. Perilaku ini tercermin pada banyaknya pohon-pohon, taman-taman yang dibangun, kebersihan sekolah, dan perilaku mencintai alam sekitar. Sikap ini menjadi faktor keharmonisan manusia dengan alam.

e. Nilai Keadilan dan Kesetaraan

Di kehidupan dan interaksi sosial, kita sangat mudah mengatakan "adil", namun sangat-sangat sukar dalam implementasinya. Terkadang apa yang kita sampaikan belum 
tentu kita bisa lakukan dengan seadil-adilnya. Nilai keadilan mengandung makna seimbang. Jika kita analogikan seperti "neraca", bahwa muatan neraca tidak bisa berat sebelah, harus sama rata dan seimbang. Keadilan juga berkaitan dengan nilai keharmonisan, sebab jika pihak sekolah telah mampu berpihak adil dalam setiap pengambilan keputusan maka suasana yang harmonis akan dapat terwujud. Pengelolaan sekolah memiliki tantangan yang untuk dapat menyeimbangkan antara hak dan kewajiban dari setiap warga sekolah. Nah disinilah dalam pengelolaan sekolah para pemimpin sekolah, guru-guru, pegawai/staf sekolah dituntut untuk dapat berlaku adil, demikian juga siswanya juga harus dapat bersifat adil dalam pergaulan.

\section{Metode internalisasi nilai-nilai multikultural}

Upaya internalisasi nilai-nilai multikultur dalam pengelolaan pendidikan ini dilakukan dengan beberapa metode-metode baik dalam kegiatan intra kurikuler dan ekstra kurikuler. Beberapa metode internalisasi tersebut yakni:

a) Internalisasi Nilai-Nilai Multikultur Dalam Visi Dan Misi

Visi dan misi adalah gambaran terhadap tujuan dan cara mencapai tujuan sekolah dalam periode yang ditetapkan. Gambaran terhadap visi dan misi sekolah dari berbagai pernyataan-pernyataan yang telah diungkapkan oleh informan bahwa, memang dalam visi dan misi sekolah belum mencantumkan kata "multicultural", namun dalam penerapannya telah dilakukan. Secara eksplisit kata multikultural belum tergambar dalam visi dan misi, namun secara faktual dan empirik telah dilakukan dan diterapkan

b) Internalisasi Nilai Multikultur Dalam Mata Pelajaran

Kemampuan guru untuk mentransfer ilmu dan pengetahuan bergantung pada metode yang diterapkan kepada peserta didiknya. Metode berkaitan dengan cara atau langkah-langkah, tahapan yang dikerjakan untuk mewujudkan tujuan dari pembelajaran. Peran guru sangatlah vital dalam upaya transfer ilmu pengetahuan.

Penanaman nilai multikultural dalam pembelajaran perlu dilakukan pengembangan model-model pembelajaran dalam mengintegrasikan nilai-nilai multikultural dalam materi pembelajaran (Lestariningsih et al., 2018; Rufaida, 2017). Integrasi ini melahirkan pola pembelajaran interaktif, pembelajaran kolaboratif dan pembelajaran student oriented (Susanto, 2011).

c) Internalisasi Nilai Multikultur Dalam Kegiatan Ekstrakurikuler

Kegiatan ektrakurikuler yang agendakan seperti: (a) memperingati Hut Gorontalo, (b) memperingati hari pendidikan Nasional serta hari nasional lainya (upacara dengan mengunakan pengantar bahasa daerah masing-masing pawai dengan mengunakan busana daerah masing-masing), (c) kegiatan kepramukaan, (d) kemah bakti, (e) pekan olahraga, (f) pekan seni dan budaya. Kegiatan-kegiatan ini sangat positif demi keberhasilan internalisasi nilai multicultural di dalam pengelolaan pendidikan

d) Internalisasi Nilai Multikultur Pada Lay Out Kelas dan Pemberian Tugas

Pengaturan lay out kelas dalam pembelajaran sangat penting dilakukan untuk menjadikan suasana pembelajaran yang kondusif. Pengatura kelas seperti model "U" telah dilakukan oleh para guru dalam melakukan pengajaran. Model ini memungkinkan siswa untuk dapat lebih banyaj berinteraksi dengan sesame siswa dan berinteraksi dengan guru mata pelajaran. Hal ini menjadi satu treatment yang baik dalam 
mengembangkan kepercayaan diri siswa untuk bisa mengajukan pernyataan, pernyataan, pendapat dan saran solusi dalam proses belajar mengajar.

e) Integrasi ke Dalam Kegiatan Perayaan Hari Besar Keagamaan dan Nasional

Dalam kondisi ini para siswa dan warga sekolah diajarkan untuk salaing mengunjungi ketika salah satu agama melaksanakan hari raya keagamaannya. Seperti yang telah diungkapkan oleh informan bahwa perayaan-perayaan hari besar keagaaman sering diikuti oleh siswa-siswa. Sebagai contoh pada hari raya idul fitri, siswa yang non Muslim datang berkunjung ke rumah siswa muslim untuk melakukan silaturahmi. Demikian juga jika agama Hindu berhari raya, seperti hari raya Galungan dan Kuningan, siswa yang beragama islam dan Kristen datang berkunjung ke rumah siswa Hindu.

\section{KESIMPULAN}

Nilai-nilai multikultur yang dikembangkan dalam intrakurikuler dan ekstrakurikuler meliputi: (a) nilai saling menghargai, (b) nilai demokrasi, (c) nilai toleransi, (d) nilai keharmonisan dan (e) nilai kesetaraan dan (f) nilai keadilan. Dalam menginternalisasi nilia-nilai multikultur dilakukan dengan beberapa metode, yakni: (i) Internalisasi Nilai Multikultur Dalam Visi dan Misi Sekolah, (ii) Internalisasi Nilai Multikultur Dalam Mata Pelajaran, (iii) Internalisasi Nilai Multikultur Dalam Kegiatan Ekstrakurikuler, (iv) Internasisasi Nilai Multikultur Pada Lay Out Kelas dan Pemberian Tugas, dan (v) Integrasi ke Dalam Kegiatan Perayaan Hari Besar Keagamaan dan Nasional.

\section{DAFTAR PUSTAKA}

Abdullah, M. A. 2005. Pendidikan Agama Era Multikultral Multireligius. Jakarta: PSAP.

Arofah, I. N. 2014. Model Pembelajaran Berbasis Masalah (Problem Based Learning) dengan Teknik Probing untuk Meningkatkan Kemampuan Berfikir Kritis Matematis Siswa. UNPAS.

Aziizu, B. Y. A. 2015. Tujuan Besar Pendidikan Adalah Tindakan. Dalam Prosiding KS: Riset \& PKM, pp. 295-300.

Bogdan, R. C. dan Biklen, K. S. 1982. Qualitative Research for Education: An Introduction to Theory and Methods. Boston London: Allyn and Bacon.

Dawam, A. 2003. Emoh Sekolah "Menolak Komersialisasi Pendidikan dan Kanibalisme Intelektual Menuju Pendidikan Multikultural “. Yogyakarta: Inspeal Press.

Furkan, N. 2012. Implementasi dan Pengembangan Pendidikan Mult ikultural di Sekolah “Al-Furqan”. Jurnal : Studi Pendidikan Islam, 1(1).

Gollnick, D. M. dan Chinn, P. C. 2006. Multicultural Education in a Pluralistic Society. Upper Saddle River, New Jersey Columbus, Ohio: Pearson Merrill Prentice Hall.

Hadi, S. 2004. Metodologi Research. Yogyakarta: Andi Offset.

Kalidjernih, F. K. 2010. Kamus Study Kewarganegaraan, Perspektif Sosiologikal dan Politikal. Bandung: Widya Aksara.

Kamalia, S. 2016. Internalisasi Nilai-Nilai Pendidikan Multicultural Pada Masyarakat Pedesaan Melalui Majelis Dzikir Wa Ta’lim "Ya Rosul” Di Desa Tambakrejo Sumbermanjing Wetan Malang. Skripsi. Program Studi Pendidikan Ilmu Pengetahuan Sosial, Jurusan Pendidikan Ilmu Pengetahuan Sosial, Fakultas Ilmu 
Tarbiyah Dan Keguruan, Universitas Islam Negeri Maulana Malik Ibrahim, Malang.

Kasinyo, H. 2012. Model Pengembangan Pendidikan Agama Islam Berbasis Multikultural. Jakarta: Grafindo.

Lestariningsih, W.A., Jayusman, dan Purnomo, A. 2018. Penanaman Nilai-Nilai Multikultural Dalam Pembelajaran Sejarah Di SMA Negeri 1 Rembang Tahun Pelajaran 2017/2018. Indonesian Journal of History Education, 6(2): 123-131.

Mahfud, C. 2010. Pendidikan Multikultural. Yogyakarta: Pustaka Pelajar.

Mahfud, C. 2014. Pendidikan Multikultural. Yogyakarta: Pustaka Pelajar.

Mashuri. 2016. Filafat Manusia: Manusia Memahami Melalui Filsafat. Bandung: PT. Remaja Rosdakarya.

Miles, M. B. dan Huberman, A. M. 1984. Analisis Data Kualitatif. Terjemahan oleh Tjetjep Rohendi Rohidi. 1992. Jakarta: Penerbit Universitas Indonesia.

Moleong, J. L. 2006. Metodologi Penelitian Kualitatif. Bandung: PT. Remaja Rosdakarya.

Mujib, A. dan Mudzakkir, Y. 2006. Ilmu Pendidikan Islam. Jakarta: Kencana Prenada Media Group.

Naim, N. dan Sauqi, A. 2010. Pendidikan Multikultural Konsep dan Aplikasi. Yogjakarta: Ar-Ruzz Media.

Rufaida, H. 2017. Menumbuhkan Sikap Multikultural Melalui Internalisasi Nilainilai Multikultural Dalam Pembelajaran IPS. SOSIO DIDAKTIKA: Social Science Education Journal, 4(1): 14-24.

Satria, A. 2017. Internalisasi Nilai-Nilai Multikultural Di Sd Nasional 3 Bahasa Putera Harapan Purwokerto. Tesis. Program Studi Ilmu Pendidikan Dasar Islam, Program Pascasarjana, Institut Agama Islam Negeri (IAIN), Purwokerto.

Scott, M. C. 2007. Effective Public Realtions, Edisi IX, cetakan ke-2. Jakarta: Kencana.

Sugiyono. 2013. Metode Penelitian Pendidikan Pendekatan Kuantitatif, Kualitatif, dan $R \& D$. Bandung: Alfabeta.

Sulalah. 2011. Pendidikan Multikultural. Malang: UIN Maliki Press.

Susanto, E. 2011. Pelaksanaan Pendidikan Agama Islam Multikultural Di Rintisan Sekolah Bertaraf Internasional SMAN 1 Pamekasan. Nuansa, 8(2): 169-182.

Usman, M., dan Widyanto, A. 2019. Internalisasi Nilai-Nilai Toleransi dalam Pembelajaran Pendidikan Agama Islam di SMA Negeri 1 Lhokseumawe, Aceh, Indonesia. DAYAH: Journal of Islamic Education, 2(1): 36-52. 
AKSARA: Jurnal Ilmu Pendidikan Nonformal

P-ISSN 2407-8018 E-ISSN 2721-7310 DOI prefix 10.37905

Volume 08, (1), January 2022

http://ejurnal.pps.ung.ac.id/index.php/Aksara 